\title{
Эффект укорочения импульсов в активной среде Үb волоконных лазеров с синхронной модуляцией накачки
}

\author{
Б.Н. Нюшков ${ }^{1,2^{*}}$, С.В. Смирнов ${ }^{1}$, А.В. Иваненко ${ }^{1}$, \\ А.Ю. Кутищева ${ }^{2}$, И.И. Корель ${ }^{2}$, С.М. Кобцев ${ }^{1}$ \\ ${ }^{1}$ Новосибирский государственный университет \\ ${ }^{2}$ Новосибирский государственный технический университет \\ ${ }^{*}$ E-mail: b.nyushkov@nsu.ru
}

DOI: 10.31868/RFL2020.73-74

Синхронная накачка является эффективным методом активной синхронизации мод излучения в различных типах лазеров [1-3], включая волоконные лазеры на основе эффекта вынужденного комбинационного рассеяния $[4,5]$. Однако в волоконных лазерах с усилением на основе вынужденного излучения, использующих непосредственную диодную накачку, возможности такого метода не были исследованы в полной мере. Формирование коротких импульсов этим методом предполагает поддержание с помощью быстро-модулируемой накачки соответствующей динамики усиления в условиях долгоживущего верхнего лазерного уровня активной среды. В данной работе мы исследовали экспериментально и теоретически режимы импульсной генерации, инициируемые синхронной модуляцией накачки в $\mathrm{Yb}$ волоконных лазерах. В результате обнаружена возможность существенного снижения требований к скорости и динамическому диапазону модуляции мощности накачки при реализации синхронной накачки на длине волны 0,98 мкм в Yb волоконных лазерах. Нами показано, что даже медленная (микросекундная) синусоидальная модуляция с малым индексом $(\leq 0.5)$ может обеспечить формирование регулярной последовательности наносекундных лазерных импульсов. Обнаружено, что энергетически-консервативный процесс укорочения (относительно периода модуляции) генерируемых лазерных импульсов может иметь место в квази-двухуровневой лазерной активной среде вследствие ассиметричного усиления переднего и заднего фронтов лазерного импульса при определенной отстройке частоты модуляции от частоты кратной собственной межмодовой частоте резонатора. Таким образом, в тестовой конфигурации Yb волоконного лазера с километровым резонатором экспериментально были получены наносекундные лазерные импульсы с энергией, превышающей 50 нДж (Рис. 1).

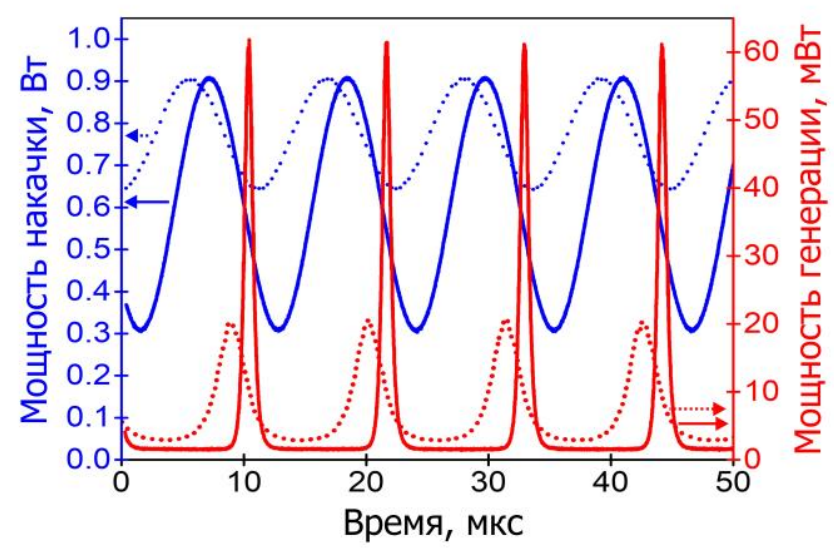

Рис. 1. Осциллограммы, показывающие модуляцию мощности накачки (обозначены синим цветом) и генерируемые лазерные импульсы (красным цветом). 
Исследованная теоретическая модель формирования импульсов при синхронной модуляции накачки (опирающаяся на численную модель эффективно двухуровневой активной среды [6]) позволила выявить пути к дальнейшему укорочению импульсов посредством настройки модуляционных параметров. Это открывает возможности для создания новых полностью волоконных высокоэнергетических импульсных лазерных источников с синхронизацией мод, которые могут стать более надежной и энергоэффективной, простой в реализации альтернативой наносекундным сверхдлинным волоконным лазерам с пассивной $[7,8]$ и традиционной (с использованием модуляторов) активной [9] синхронизацией мод.

Работа выполнена при частичной поддержке Министерства науки и высшего образования РФ (FSUS-2020-0036).

\section{Литература}

[1] D.S. Peter, P. Beaud et al, Opt. Lett. 16, 405-407 (1991)

[2] E. Granados, H.M. Pask, and D.J. Spence, Opt. Express 17, 569-574 (2009)

[3] B.N. Nyushkov, S.M. Kobtsev et al, J. Opt. Soc. Am. B 35, 2582-2587 (2018)

[4] S. Kobtsev, A. Ivanenko et al, Opt. Express 26, 29867-29872 (2018)

[5] D.S. Kharenko, V.D. Efremov et al, Opt. Express 26, 15084-15089 (2018)

[6] S.K. Turitsyn, A.E. Bednyakova et al., Opt. Express 19, 8394-8405 (2011)

[7] S. Kobtsev, S. Kukarin, and Y. Fedotov, Opt. Express 16, 21936-21941 (2008)

[8] B.N. Nyushkov, A.V. Ivanenko et al, Laser Phys. Lett. 9, $59-67$ (2012)

[9] N.A. Koliada, B.N. Nyushkov et al, Quantum Electron 43, 95-98 (2013) 